\title{
Serological, Pathological and Molecular Characterisation of Hungarian Pepper Mild Mottle Tobamovirus (PMMoV) Isolates*
}

\author{
D. KÁLMÁN 1 , L. PALKOVICS² and R. GÁBORJÁNYI ${ }^{3}$ \\ ${ }^{1}$ Plant Protection Institute, Hungarian Academy of Sciences, H-1525 Budapest, P.O. Box 12, Hungary \\ ${ }^{2}$ Agricultural Biotechnology Center, H-2101 Gödöllö, P.O. Box 411, Hungary \\ 3Plant Protection Institute, Veszprém University, Georgikon Faculty of Agricultural Sciences, \\ H-8631 Keszthely, P.O. Box 71, Hungary
}

Last year pepper growers observed symptoms referring to virus-infection in pepper plantations in plastic tunnels. Infected plants showed mosaic symptoms or mottling of the leaves, while on the fruits necrotic spots developed. These symptoms referred to a tobamovirus infection. Collected samples were examined by serological and pathological methods, followed by the biological characterisation of the isolates. For serological studies the DAS-ELISA method was used, in which the pathogen was identified as pepper mild mottle tobamovirus. During the pathological examination different host-plants have been used including some pepper varieties containing different $\mathrm{L}$ genes $\left(\mathrm{L}^{+}-\mathrm{L}^{4}\right)$. It was found, that the Hungarian isolates belonged to the $\mathrm{P}_{1,2}$ pathotype and were closely related to the Spanish isolate (PMMV-S). PCRstudies proved the presence of the PMMoV $\mathrm{P}_{1,2}$ pathotype in Hungary as well.

Keywords: Pepper mild mottle virus, tobamovirus, PCR.

It is well known that among pepper diseases the viruses play a major role. Pepper is a natural host of about 45 plant-pathogen viruses (Green and Kim, 1991; Gáborjányi et al., 1997, 1998). These viruses cannot be diagnosed only by the symptoms, as one virus can cause different symptoms, and similar symptoms can derive from different pathogens as well.

Tobamovirus group is an important and separate group of pepper viruses (Table 1), causing serious yield losses especially in the greenhouses or plastic tunnels. Its first member is the tobacco mosaic tobamovirus (TMV) mentioned at first more, than 100

Table 1

Pepper-pathogen tobamoviruses

(Viruses in bold type are officially recorded by ICTV)

\begin{tabular}{ll}
\hline Virus & First description \\
\hline Tobacco mosaic tobamovirus (TMV) & Mayer, 1886 \\
Tomato mosaic tobamovirus (ToMV) & Clinton, 1909 \\
Tobacco mild green mosaic tobamovirus (TMGMV) & McKinney, 1929 \\
Pepper mild mottle tobamovirus (PMMoV/ PMMV) & McKinney, 1952 \\
Bell pepper mottle virus (BePMV) & Feldman and Oremianer, 1972 \\
Paprika mild mottle tobamovirus (PaMMV) & Rast, 1979 \\
Dulcamara yellow fleck virus (DYFV) & Salamon et al., 1987a,b \\
\hline
\end{tabular}

*Dedicated to the occasion of the 65th birthday of Professor József Horváth 
years ago (Mayer, 1886; Linhart and Mezey, 1890). After the first description of TMV in Hungary (Szirmai, 1950) many papers dealt with tobamoviruses. Horváth (1969) tested different pepper varieties to TMV resistance but did not find resistant varieties among the cultivated sweet and red peppers. The breeders concentrated first on the incorporation of $\mathrm{L}^{1}$ gene into different varieties (Zatykó, 1982). The first tobamovirus in Hungary which overcame the resistance provided by the $\mathrm{L}^{1}$ gene was isolated in 1980 as ToMV-Ob (Csilléry and Ruskó, 1980). Later Salamon et al. (1987a,b) reported a new pathotype named dulcamara yellow fleck. Burgyán et al. (1978) drew the attention to the heterogeneity of the tobamoviruses isolated in Hungary, proving that isolates from infected pepper, tomato, tobacco and Solanum dulcamara could be grouped both by their hostplant reactions and serological features. Isolates deriving from pepper represented more independent types. Tóbiás et al. $(1982 ; 1983)$ dealt especially with the symptomatological and serological behaviour of different tobamovirus isolates. They gave a detailed comparison of six pepper-pathogen tobamoviruses including the Hungarian ToMV-Ob isolate and the TMV-SL isolate (later separated as a new virus species, pepper mild mottle virus by Wetter, 1984a,b). Pepper mild mottle tobamovirus (PMMoV/PMMV) meant a new and special problem for pepper production. The virus produced slight mottling or no symptoms on the leaves, but caused chlorotic mottling, malformation and reduction in size with occasional necrotic spots on the fruits (Wetter et al., 1984a,b; Avgelis, 1986; Alonso et al., 1989).

The presence of this pathogen in Hungary was supposed earlier. Tóbiás and Csilléry (1983) reported a new TMV pepper strain which systemically infected the peppers containing the $\mathrm{L}^{1}$ gene. The samples were examined on indicator plants and with ELISA tests. According to these the infected samples gave positive reaction with the TMV-SL antiserum and the isolates represented at least a pathotype of $\mathrm{P}_{1}$. However it was not further examined, if $\mathrm{P}_{1}$, or a more aggressive pathotype was present. In a former paper Salamon (1993) mentioned the isolation of PMMV, however, no detailed description was reported about the isolate called PMMV-Nov, except the host-plant tests on the pepper varieties containing different $\mathrm{L}$ genes. It was indicated, that PMMV-Nov belonged to the $\mathrm{P}_{1,2,3}$ pathotype. Kiss (1996) reported about the infection of PMMV diagnosed by DASELISA in the region of county Csongrád. Our isolates probably represent a new $\left(\mathrm{P}_{1,2}\right)$ pathotype of PMMoV in Hungary. The aim of our work is to characterise these isolates by different methods, to compare them with other tobamoviruses and work out a PCR method to identify separately the different tobamovirus isolates causing heavy losses in the pepper-plantations.

PMMoV became very important especially in the Mediterranean pepper-growing countries, causing more and more losses (Selassie et al., 1981; Wetter et al., 1984a,b; Avgelis, 1986; Betti et al., 1988; Alonso et al., 1989). Now it seems that it occurs often in the plastic tunnels in Hungary and causes quality degradation of the fruits. Because of the internal seed transmission (Tošić et al., 1980; Tanzi et al., 1989) its presence means a real threat for the pepper production.

As the molecular techniques became general in virology, researchers began to characterise this virus at molecular level too. The nucleotide sequence of its 5' and 3 ' non- 
coding regions was reported in 1989 (Avila-Rincón et al., 1989), followed by the cloning and the complete nucleotide sequence of PMMV-S (Alonso et al, 1991). A procedure involving reverse transcription followed by polymerase chain reaction (RT-PCR) was developed for typing pathotypes of the tobamoviruses infecting the L-resistant genotypes of pepper (Tenllado et al., 1994), and to separate the two pathotypes, which cannot be differentiated by serological means. For these reasons PaMMV and PMMV specific primers were used. The discrimination between the two pathotypes was achieved by restriction enzyme analysis of the PCR products. Tenllado et al. (1997) applied the PCR method for the screening of pathotypes in field isolates.

\section{Tobamovirus pathotypes}

Differentiation of pepper-pathogen tobamoviruses is based on the resistance of wild Capsicum species. Resistance in the Capsicum species is provided by five, dominantly inherited $\mathrm{L}$ genes $\left(\mathrm{L}^{+}, \mathrm{L}^{1}, \mathrm{~L}^{2}, \mathrm{~L}^{3}, \mathrm{~L}^{4}\right)$, located on the same locus and localising the infection in an incomplete way. In contrast to it the virus has four pathotypes $\left(\mathrm{P}_{0}, \mathrm{P}_{1}, \mathrm{P}_{1,2}\right.$, $\left.\mathrm{P}_{1,2,3}\right)$. The different compatible or incompatible pepper-virus relationships are summarised in Table 2. The pepper containing the $\mathrm{L}^{+}$gene is susceptible to the infection of any pathotypes. The resistance gene $\mathrm{L}^{1}$ provides resistance against the $\mathrm{P}_{0}$ pathotype, the $\mathrm{L}^{2}$ gene against the $\mathrm{P}^{1}$ pathotype, etc. If pepper varieties of a certain resistance level are grown for a long period of time, one could observe the tendency, that the virus overcomes the resistance, and a more aggressive strain appears.

Table 2

Relationship of pepper varieties with different resistance level and tobamoviruses of different pathotypes (according to Rast, 1979, 1988; Boukema et al.,

1980; Tóbiás et al., 1982; and Boukema, 1984)

\begin{tabular}{ccccc}
\hline \multirow{2}{*}{ Resistance genes } & \multicolumn{3}{c}{ Pathotypes } & \\
\cline { 2 - 5 } & $\mathrm{P}_{0}$ & $\mathrm{P}_{1}$ & $\mathrm{P}_{1,2}$ & $\mathrm{P}_{1,2,3}$ \\
\hline $\mathrm{L}^{+}$ & $\mathrm{S}$ & $\mathrm{S}$ & $\mathrm{S}$ & $\mathrm{S}$ \\
$\mathrm{L}^{1}$ & $\mathrm{R}$ & $\mathrm{S}$ & $\mathrm{S}$ & $\mathrm{S}$ \\
$\mathrm{L}^{2}$ & $\mathrm{R}$ & $\mathrm{S}$ & $\mathrm{S}$ \\
$\mathrm{L}^{3}$ & $\mathrm{R}$ & $\mathrm{R}$ & $\mathrm{S}$ \\
$\mathrm{L}^{4}$ & $\mathrm{R}$ & $\mathrm{R}$ & $\mathrm{R}$ & $\mathrm{R}$ \\
\hline
\end{tabular}

$\mathrm{S}$ = susceptibility, $\mathrm{R}=$ resistance.

According to Betti et al. $(1986,1988)$ the reason for increasing crop losses was due to the higher level of pathogenicity of the tobamoviruses. If one TMV isolate $\left(\mathrm{P}_{0}\right)$ was maintained on a $\mathrm{L}^{+} / \mathrm{L}^{1}$ heterozygote plant within controlled circumstances by repeated passage, the virus overcame the $\mathrm{L}^{1}$ resistance. Similarly, more aggressive isolate developed when the virus strain was prolonged on more resistant $\left(\mathrm{L}^{1}\right.$ or $\left.\mathrm{L}^{2}\right)$ plants. The increase of pathogenicity on pepper was accompanied by the decreased pathogenicity to tobacco. The virus strain was gradually adapted to the new host and collaterally was losing its 
relationship to the original host-plant. On the basis of these facts it could be theoretically supposed, that such pathological change ensued under the Hungarian growing conditions too. Our pepper production is more and more exposed to the appearance of new isolates with higher pathogenicity. The reason of increasing pathogenicity was the preference of resistant varieties, with no hypersensitive response. In these cases the pathogen could replicate at a lower level, but could adapt gradually. If more pathogenic strains became dominant in the population it could be a starting-point for heavy epidemics.

\section{Materials and Methods}

In the autumn of 1999 eighteen samples were collected from the infected peppers grown under plastic tunnels in the region of "Jászság" (Middle Hungary). Plants showed mild mosaic leaf symptoms or were symptomless, but necrotic spots developed on the fruits before ripening. First isolates were tested by serological methods followed by hostplant tests and molecular characterisation.

For serological examination the DAS-ELISA method was used according to Clark and Adams (1977), following the instructions of the producers of the ELISA-kit. After collecting the samples they were immediately deep-frozen, and a few days later homogenised in extraction buffer $(1: 2.5 \mathrm{~g} / \mathrm{ml})$, and tested with polyclonal antisera (Loewe Phytodiagnostica). Tests were made to the following viruses: tobacco mosaic tobamovirus (TMV), tomato mosaic tobamovirus (ToMV), pepper mild mottle tobamovirus (PMMoV), potato X potexvirus (PVX), potato Y potyvirus (PVY), alfalfa mosaic alfamovirus (AMV), and cucumber mosaic cucumovirus (CMV).

Pepper species with different resistance level and 3 different tobacco species were used for the host-plant tests (Table 3). The resistance level of pepper varieties was the following: $\mathrm{L}^{+}$(Albaregia, Synt. Cecei), $\mathrm{L}^{1}$ (D. Cecei, Fehérözön), L ${ }^{2}$ (Greygo), L ${ }^{3}$ (Bölény, Rapires), $\mathrm{L}^{4}$ (Hímes). The deep-frozen samples were homogenised in phosphate buffer $(0.1 \mathrm{M})$ according to Sörensen $(\mathrm{pH} 7.0 ; 1: 5 \mathrm{w} / \mathrm{v})$ in a mortar with pestle, and the leaves of the host-plants were inoculated mechanically. On peppers the cotyledons, on tobaccoes the lower 3-4 leaves were inoculated. To improve the efficiency of the inoculation silicium carbide (Carborundum $500 \mathrm{mesh}$ ) dust was added. The plants were kept in glasshouse $\left(18-25^{\circ} \mathrm{C} ; 160 \mathrm{mEm}^{-2} \mathrm{~s}^{-1}\right.$ additional lighting for 8 hours a day; relative humidity $60 \%$ ). Local symptoms were checked after 4-7 days, and systemic symptoms after 3-4 weeks.

For the molecular studies a universal primer pair was designed to recognise the most tobamoviruses. Sequences of the tobamoviruses were taken from the Genbank of EMBL Data Library, DNA Data Bank of Japan. The most important viruses under the Hungarian conditions were selected because of the great amount of the tobamovirus sequences. We tried to find a section, what was quite the same in every (or at least in the most important) tobamoviruses, where the universal primer pair was designed (Fig. 1). The 5 ' primer was constructed in front of the coat protein $(\mathrm{CP})$ gene, it was degenerated and virussense. The 3' primer was also degenerated, reverse complementary and situated in the 
Table 3

Symptoms of indicator plants inoculated with the samples identified as PMMoV by DAS-ELISA

\begin{tabular}{|c|c|c|c|c|c|c|c|c|}
\hline Isolates* & $\begin{array}{c}\text { CPSAN }^{* *} \\
\mathrm{~L}^{+}\end{array}$ & $\begin{array}{c}\text { CPSAN } \\
\mathrm{L}^{1}\end{array}$ & $\begin{array}{c}\text { CPSAN } \\
\mathrm{L}^{2}\end{array}$ & $\begin{array}{c}\text { CPSAN } \\
\mathrm{L}^{3}\end{array}$ & $\begin{array}{c}\text { CPSAN } \\
\mathrm{L}^{4}\end{array}$ & $\begin{array}{l}\text { NIOTA- } \\
\text { XNC }\end{array}$ & $\begin{array}{l}\text { NIOTA- } \\
\text { SAM }\end{array}$ & NIORU \\
\hline $\mathrm{Ca} 2$ & $-/ \mathrm{Mot}^{* * *}$ & -/Mot & $-/-$ & $\mathrm{Ab} /-$ & $\mathrm{Ab} /-$ & LLe/- & $-/ \mathrm{s}$ & LLe/- \\
\hline $\mathrm{Ca} 2 \mathrm{a}$ & -/Mot & -/Mot & $-1-$ & $\mathrm{Ab} / \mathrm{N}$ & $\mathrm{Ab} /-$ & LLe/- & $-/ \mathrm{M}$ & LLe/- \\
\hline $\begin{array}{l}\mathrm{Ca} 4 \mathrm{a} \\
\text { (mixed with } \\
\text { PVY) }\end{array}$ & $-/$ Mot & -/Mot & $-1-$ & $\mathrm{Ab} /-$ & $\mathrm{Ab} /-$ & $\begin{array}{l}\text { LLe/ } \\
\text { VN,N, } \\
\text { M, } \\
\text { Ch }\end{array}$ & $-/ \mathrm{s}$ & LLe/- \\
\hline $\mathrm{Ca} 5 \mathrm{a}$ & -/Mot & -/Mot & $-1-$ & $\mathrm{Ab} /-$ & $\mathrm{Ab} /-$ & LLe/- & $-/ \mathrm{N}, \mathrm{VN}$ & LLe/- \\
\hline $\begin{array}{l}\text { Ca } 5 \text { b (mixed } \\
\text { with CMV) }\end{array}$ & $-1-$ & -/Mot & $-1-$ & $\mathrm{Ab} /-$ & $\mathrm{Ab} /-$ & LLe/- & $-/ \mathrm{s}$ & LLe/- \\
\hline $\mathrm{Ca} 6$ & $-1-$ & -/Mot & -1 & $\mathrm{Ab} /-$ & $\mathrm{Ab} /-$ & LLe/- & $-/ \mathrm{s}$ & LLe,N/- \\
\hline $\mathrm{Ca} 7$ & -/Mot & $-/$ Mot & $-1-$ & $\mathrm{Ab} /-$ & $\mathrm{Ab} /-$ & LLe/- & $-/ \mathrm{s}$ & LLe/- \\
\hline $\begin{array}{l}\text { Ca } 8 \text { (mixed } \\
\text { with PVY) }\end{array}$ & $-/ \mathrm{Mot}$ & $-/$ Mot & $-1-$ & $\mathrm{Ab} /-$ & $\mathrm{Ab} /-$ & $\begin{array}{l}\text { LLe/ } \\
\text { M, } \\
\text { VN }\end{array}$ & $\begin{array}{c}\mathrm{Ch} / \\
\mathrm{VN}, \mathrm{N}\end{array}$ & $\begin{array}{l}\text { LLe,Ch } \\
\text { /- }\end{array}$ \\
\hline $\begin{array}{l}\text { Ca } 10 \text { (mixed } \\
\text { with ToMV) }\end{array}$ & -/Mot & -/Mot & $-1-$ & $\mathrm{Ab} /-$ & $\mathrm{Ab} /-$ & LLe/- & $-/ \mathrm{s}$ & LLe/- \\
\hline
\end{tabular}

Key:

* Ca 2, Ca 2a, Ca 4a, Ca 5a, Ca 5b, Ca 6, Ca 7, Ca 8, Ca $10=$ pepper isolates,

$\mathrm{PVY}=$ potato $\mathrm{Y}$ virus, $\mathrm{CMV}=$ cucumber mosaic virus, ToMV = tomato mosaic virus.

** Abbreviations of host-plants are used according to Horváth (1993). CPSAN = Capsicum annuum, NIOTA$\mathrm{XNC}=$ Nicotiana tabacum $\mathrm{cv}$. Xanthi- $n c$, NIOTA-SAM = Nicotiana tabacum cv. Samsun, NIORU = Nicotiana rustica.

*** Abbreviations of local symptoms can be seen in the numerator, while systemic symptoms are indicated in the denominator. Mot = mottling; $-=$ no symptoms; $\mathrm{Ab}=$ abscission; $\mathrm{L}=$ local; $\mathrm{Le}=$ lesion; $\mathrm{Ch}=$ chlorosis; $\mathrm{VN}=$ vein necrosis; $\mathrm{N}=$ necrosis; $\mathrm{M}=$ mosaic; $\mathrm{s}=$ symptomless infection (detected with back inoculation to Nicotiana tabacum cv. Xanthi-nc).

3' non-coding region. The universal primer pair was successfully tried out with own and authentic isolates. The authentic isolates originated from the stock-collection of the Plant Protection Institute. The PCR was carried out according to the following description:

Nicotiana tabacum cv. Samsun plants were mechanically infected as mentioned above with the own and authentic isolates. Samples of $0.1 \mathrm{~g}$ were taken about 3-4 weeks after the inoculation from the systemically infected leaves. Total RNA was extracted from plant tissues, using the following method: samples were homogenised in $600 \mu \mathrm{l}$ extraction buffer (pH 7.6 containing 5\% TRIS (1.0 M), 2\% NaCl (5.0 M), 0.2\% EDTA (0.5 M), 5\% SDS (10\%), $0.3 \%$ mercaptho-ethanol in $100 \mathrm{ml}$ distilled water) adding $600 \mu \mathrm{l}$ phenol, then centrifuged for 5 minutes $(15000 \mathrm{rpm}) .300 \mu \mathrm{l}$ phenol and $300 \mu \mathrm{l}$ chloroform was added to the supernatant and centrifuged for 5 minutes. After adding $600 \mu \mathrm{l}$ chloroform to the supernatant the centrifugation was repeated, and adding $1 \mu$ absolute alcohol to the supernatant was followed by centrifugation (10 $\mathrm{min}$ ) again. The total RNA was precipitated and washed with ethanol (70\%), then after drying suspended in sterile distilled water $(60 \mu \mathrm{l})$. 


\section{a. The 5' end of the primer pair}

TMV-Ob TATGAGTCAG GACGGTAGCT CAAGCGAGAT ATCATCCGAT TCGTTTATTT TMV-U1 . ATCGATGAT GATTCGGAGG CTACTGTCGC CGAATCGGAT TCGT . . .TTT PMMoV .ATTGGGCAG AACTCGGAGT CATCGGACGC CGAGTCTTCT TCGT. . .TTT Univers. 5 GACGC GGAGTCGGAT TCGT ATT

$\downarrow$ CP start

TMV-Ob AATCATGCCT TATACTGTTA CGTCTCCAAG CCAACTAGTT TATTTTGGTT TMV-U1 AAATATGTCT TACAGTATCA CTACTCCATC TCAGTTCGTG TTCTTGTCAT PMMOV AACTATGGCT TACACAGTTT CCAGTGCCAA TCAATTAGTG TATTTAGGTT Univers. AAATATG $\quad 3$ '

\section{b. The 3 ' end of the primer pair}

TMV-Ob TACGACTATA AAAATAAGAA GGGGTTCGAA TCCCCCCCGT ACCCCGGGTA TMV-U1 CAGGCACGT. AATAAAGCGA GGGGTTCGAA TCCCCCCGTT ACCCCCGGTA PMMOV AACGACGTAA TTATTTTTCA GGGGTTCGAA TCCCCCCCGA ACCGCGGGTA

TMV-Ob GGGGCCCA

TMV-U1 GGGGCCCA

PMMOV GCGGCCCA

Universal: $\quad 5$ 'TGGGCC (GC) CTACC (GC) G (GC) GG 3'

Fig. 1. The universal primer pair

\section{a. The TMV-Ob specific primer.}

TMV-Ob ATAGTATAGG AGTTTCCAAA CCTGTCGGTT TGGAAAGAAA TAAAGTAAGG TMV-U1 AAAATAGTAG TAATGATCGG TCAGTGCCGA ACAAGAACTA TAGAAATGTT PMMOV AGAGAAATGA TAATAAGGGT T. . . . . TGA ATAAGGAAGG GAAGCTGTTT

\section{b. The TMV-U1 specific primer.}

TMV-Ob GGGAATCAGT TTCAAACACA GAATGCGAGA ACTACTGTAC AACAGCAGTT TMV-U1 GGAAATCAGT TTCAAACACA ACAAGCTCGA ACTGTCGTTC AAAGACAATT PMMOV GGCAATCAGT TTCAAACACA ACAGGCTAGA ACTACGGTTC AACAGCAGTT

TMV-Ob CAGTGATCTG TTTAAGACTG TTCCCACTAG GACCAATAGG TTCAATGATG TMV-U1 CAGTGAGGTG TGGAAACCTT CACCACAAGT AACTGTTAGG TTCCCTGACA PMMOV CTCTGATGTG TGGAAGACTA TTCCGACCGC TACAGTTAGA TTTCCTGCTA

\section{c. The PMMoV specific primer.}

TMV-Ob CTGTTTGGGC GGATCCGATT ACATTTATCG ATCTTTGTAC CGTGGCCTTG TMV-U1 CAGCGTGGGC CGACCCAATA GAGTTAATTA ATTTATGTAC TAATGCCTTA PMMOV CTGTATGGGC TGATCCATTA GAGTTACAAA ATCTGTGTAC TTCGGCGTTA 
For cDNA synthesis, $1 \mu \mathrm{l} 3$ ' primer (100 pmol/ $\mu \mathrm{l} \mathrm{cc}$.) and $3.75 \mu \mathrm{l}$ distilled water was added, and denaturised at $65^{\circ} \mathrm{C}$ for 5 minutes. Afterwards $2 \mu$ reverse-transcriptase buffer $(5 \mathrm{x}), 0.25 \mu \mathrm{l}$ reverse-transcriptase enzyme and $1 \mu \mathrm{lNTP} \operatorname{mix}(5 \mathrm{mM})$ was added to the mixture, and kept at $42{ }^{\circ} \mathrm{C}$ for one hour. In the final reaction tube $2 \mu \mathrm{l}$ of the former synthetised DNA, $5 \mu \mathrm{l}$ PCR buffer (10x), $3 \mu \mathrm{lgCl}_{2}(25 \mathrm{mM}), 2 \mu \mathrm{dNTP} \operatorname{mix}(5 \mathrm{mM})$, $1-1 \mu \mathrm{l}$ of both primers, and $36 \mu \mathrm{l}$ distilled water was mixed and $0.5 \mu \mathrm{l}$ Taq polymerase enzyme was added. The enzymes and reagents were produced by Fermentas. The amplifications were carried out using the following programme: $94{ }^{\circ} \mathrm{C}$ denaturation for 3 minutes, 35 cycles (one cycle was consisted of $94^{\circ} \mathrm{C}$ for 15 seconds, $60{ }^{\circ} \mathrm{C}$ annealing for 30 seconds, $72{ }^{\circ} \mathrm{C}$ extension for 2 minutes) and 10 minutes final extension at $72{ }^{\circ} \mathrm{C}$. The PCR-products were analysed in agarose gel $(1.2 \%)$ in the presence of $0.001 \%$ ethidium bromide, using $45 \mathrm{mM}$ Tris-borate $\mathrm{pH} 8.01 \mathrm{mM}$ EDTA (TBE) as electrophoresis buffer (Sambrook et al., 1989) at $120 \mathrm{~mA}$.

Specific primers were designed to the most important tobamoviruses (Fig. 2). These primers were created to a section, where the other tobamoviruses were different. (The 3' primer of the universal primer pair was used as the other half of these specific primer pairs.) The TMV-Ob specific primer was situated in front of the $\mathrm{CP}$ gene, while the TMV-U1 specific primer and the PMMoV specific primer were located in the CP gene. During the designing of the specific primers we had the aim to construct primers recognising different-sized PCR products (Fig. 3). Later we would like to use them in a multiplex-PCR, in which the tobamoviruses could be identified according to the size of the PCR products. The specific primers were also tested with more isolates following the description detailed above.

Universal primer pair:

in case of PMMoV: 699 bp

in case of TMV-U1: $709 \mathrm{bp}$

in case of TMV-Ob: $782 \mathrm{bp}$

\section{Specific primers:}

in case of PMMoV: $613 \mathrm{bp}$

in case of TMV-U1: $555 \mathrm{bp}$

in case of TMV-Ob: $899 \mathrm{bp}$

Fig. 3. The estimated length of the sections recognised by the primers

\section{Results}

In ELISA tests 9 samples were infected by PMMoV, from which 4 were infected with other viruses too. Altogether 3 samples were infected by CMV, 4 by PVY, and 1 by ToMV. In some cases complex-infection was detected, but no pathogen was found in 5 samples. 
Tests were continued with samples containing the PMMoV. Symptoms were summarised in Table 3. Most isolates caused systemic mottling on the pepper varieties containing the $\mathrm{L}^{+}$or $\mathrm{L}^{1}$ gene, while no mottling could be detected on the pepper varieties of $\mathrm{L}^{2}$ resistance level. Pepper varieties containing the $\mathrm{L}^{3}$ or $\mathrm{L}^{4}$ gene were resistant, responded to the infection with leaf-abscission (hypersensitive response). On Nicotiana tabacum cv. Xanthi- $n c$ plants local lesions were observed in every case, no systemic infection occurred except in the case of mixed-infection, where the other viruses of the complex (CMV, PVY) could be responsible for the systemic symptoms. On the Nicotiana rustica plants local lesions developed, but no symptoms were observed at all on Nicotiana tabacum cv. Samsun.

A lot of examinations have been carried out with the universal primer pair to find the best parameters and to prove that this primer pair was able to recognise the tobamovirus isolates. Fig. 4 demonstrates the results of a PCR examination where different authentic and own isolates were recognised by the universal primer pair. On the basis of PCR products every isolate proved to be a tobamovirus. On the other hand, the universal primer pair was able to recognise every tobamovirus isolates.

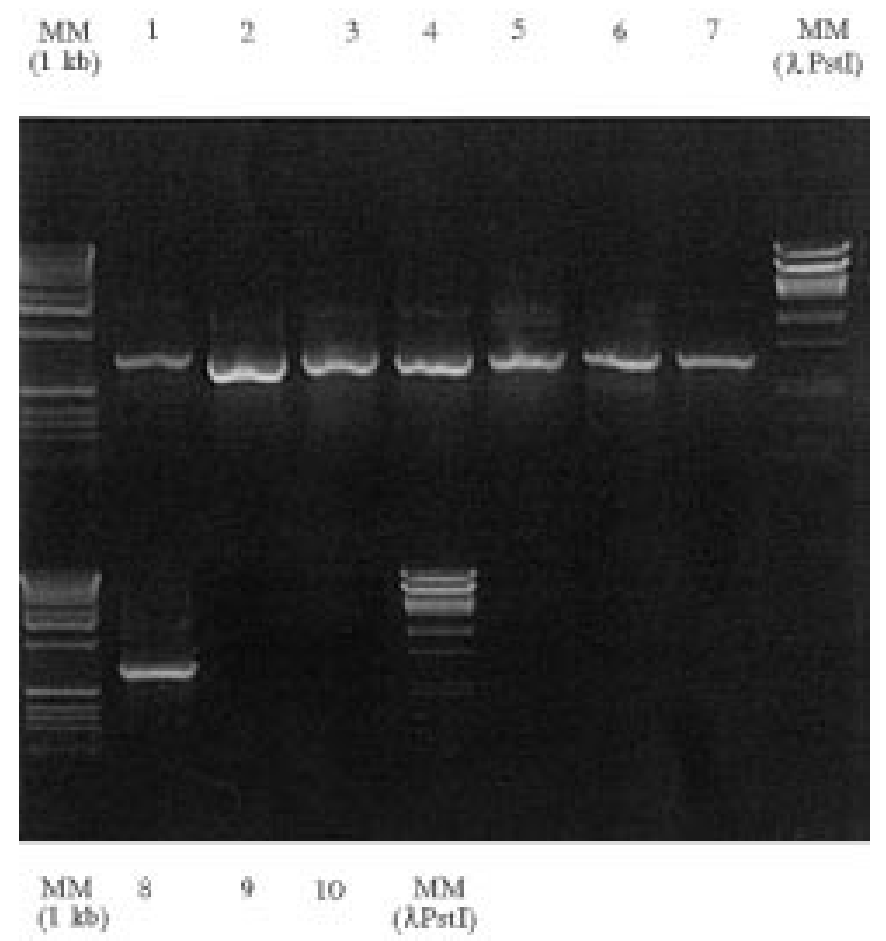

Fig. 4. PCR examination of the $\mathrm{Ca} 2$ isolate using the universal and the PMMoV virus-specific primers. PCR products were analysed in agarose gel (1.2\%). Line 1: isolate Ca 2 with the universal primer pair (699 bp); lines 2-3: isolate Ca 2 with the PMMoV-specific primer (in repetition, $613 \mathrm{bp}$ );

line 4: TMV-U1 isolate with the TMV-U1 specific primer (as comparison, $555 \mathrm{bp}$ );

MMa: size-marker (1 kb); MMb: size-marker $(\lambda \mathrm{PstI})$ 
Fig. 5 shows a PCR test. One of our isolates, called Ca 2 (identified as PMMoV with ELISA and test plants) was tested with the universal and PMMoV specific primers. PCR products were detected by using the universal primer pair, as well as with the PMMoV specific primer. It confirmed the former results, that the isolate $\mathrm{Ca} 2$ was PMMoV. Naturally, the isolate Ca 2 was tested with the TMV-U1 and TMV-Ob primer as well, but in these cases - as it was expected - no PCR products were detected.

$\begin{array}{cccccc}\mathrm{MM} & 1 & 2 & 3 & 4 & \begin{array}{c}\mathrm{MM} \\ (1 \mathrm{~Pb})\end{array}\end{array}$

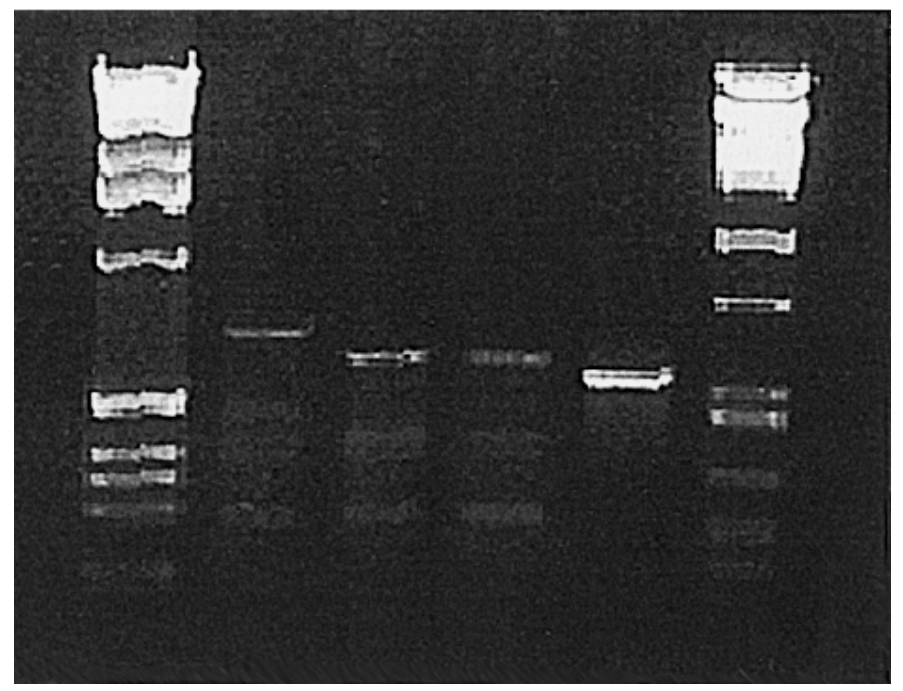

Fig. 5. PCR examination of tobamovirus isolates by using the universal primer pair. Lines 1-5: authentic tobamovirus isolates, line 1: SL 5x; line 2: SL; line 3: TMV-U1; line 4: ToMV-Ob; line 5:

ToMV D/H; lines 6-8: own isolates; line 6: And; line 7: Ca 6; line 8: Ca 5a; line 9: healthy plant; line 10: control; MMa: size-marker (1 kb); MMb: size-marker ( $\lambda$ PstI)

\section{Discussion}

PMMoV (versus PMMV) was first described by McKinney in 1952. Former synonym names of the virus were: Samsun latent strain of TMV, pepper mosaic virus, Capsicum mosaic virus, pepper unusual strain, isolate P 8, isolate P 14, SL-TMV.

Serological tests carried out with the specific antiserum of different tobamoviruses confirmed our hypothesis that a tobamovirus was present. Within the tobamovirus group the pathogen was identified as pepper mild mottle tobamovirus (PMMoV).

Two important PMMoV/PMMV isolates were separated so far, which differ in their pathotype (Boukema et al., 1980; García-Luque et al., 1990, 1993). The first one 
was the Spanish isolate (PMMV-S) a pathotype of $\mathrm{P}_{1,2}$, and the other was the Italian isolate (PMMV-I) with higher level of pathogenicity $\left(\mathrm{P}_{1,2,3}\right)$. Spanish isolate caused resistance only on the peppers containing the $\mathrm{L}^{3}$ or $\mathrm{L}^{4}$ gene, while the peppers of $\mathrm{L}^{1}$ and $\mathrm{L}^{2}$ resistance level were susceptible to its infection. The infection was symptomless on the Nicotiana tabacum cv. Samsun, while local lesions could be detected on the Nicotiana tabacum cv. Xanthi-nc and Nicotiana rustica plants. Similar symptoms could be observed in the case of the Italian isolate with the exception that only the $\mathrm{L}^{4}$ pepper was resistant to its infection.

Comparing our results to the literature data it was concluded, that our samples were infected by PMMoV. The symptoms developed on the tobacco plants were more or less coincide with the data in the literature (Tóbiás et al., 1983), while the symptoms on pepper plants decided, that from the two PMMoV isolates in Hungary the less aggressive $\mathrm{P}_{1,2}$ pathotype was found. According to the literature this pathotype caused systemic mottling on the $\mathrm{L}^{2}$ peppers, but we did not observe symptoms at all. It was probably due to the fact, that this virus - as it is shown in its name - often causes very weak or no symptoms. No leaf-abscission was observed as in case of the resistant varieties, therefore the peppers of resistance level $\mathrm{L}^{2}$ are susceptible to its infection.

Examination of the PMMoV isolates in nucleic acid level confirmed the results of our former serological and pathological studies. Tests with the universal primer pair demonstrated that the isolates belonged to the tobamovirus group, while tests carried out with virus-specific primers proved that the isolates were identical with PMMoV. The PCR-based method was efficient to identify the Hungarian tobamovirus isolates rapidly and easily using universal and virus-specific primers.

\section{Acknowledgement}

This work was partly supported by the AKP (98-53 3,1), and FEFA 0056/1999.

\section{Literature}

Alonso, E., García Luque, I., Avila-Rincón, M. J., Wicke, B., Serra, M. T. and Díaz-Ruíz, J. R. (1989): A tobamovirus causing heavy losses in protected pepper crops in Spain. J. Phytopathology, 125, 67-76.

Alonso, E., García-Luque, I., De La Cruz, A., Wicke, B., Avila-Rincón, M. J., Serra, M. T., Castresana, C. and Díaz-Ruíz, J. R. (1991): Nucleotide sequence of the genomic RNA of pepper mild mottle virus, a resistance-breaking tobamovirus in pepper. Journal of General Virology, 72, 2875-2884.

Avgelis, A. D. (1986): A pepper strain of TMV who is new in Crete (Greece). Phytopath. Medit., 25, $33-38$.

Avila-Rincón, M. J., Ferrero, M. L., Alonso, E., García-Luque, I. and Díaz-Ruíz, J. R. (1989): Nucleotide sequences of 5' and 3' non-coding regions of pepper mild mottle virus strain S RNA. Journal of General Virology, 70, 3025-3031.

Betti, L., Tanzi, M. and Canova, A. (1986): Evolutionary changes in TMV pepper strains as a result of repeated host passages. Phytopath. Medit., 25, 39-43.

Betti, L., Tanzi, M. and Canova, A. (1988): Pepper mosaic virus strains and their adaptation to the host. I. Biological and serological behaviour. Phytopath. Medit., 27, 7-17. 
Boukema, I. W., Jansen, K. and Hofman, K. (1980): Strains of TMV and genes for resistance. Capsicum, Eucarpia Working Group. Synopses of the 4th Meeting, Wageningen, $44 \mathrm{pp}$.

Boukema, I. W. (1984): Resistance to TMV in Capsicum chacoense Hunz. is governed by an allele of the Llocus. Capsicum Newsletter No. 3, 47-48.

Burgyán, J., Beczner, L. and Gáborjányi, R. (1978): Relationship among some tobamoviruses. I. Symptomatological and serological comparison. Acta Phytopathol. Acad. Sci. Hung., 13, 75-85.

Clark, M.F. and Adams A.N. (1977): Characteristics of the microplate method of enzyme-linked immunosorbent assay for the detection of plant viruses. J. Gen. Virol., 34, 475-483.

Clinton, (1909): Rep. Conn. Agric. Exp. Stn. 1907-1908, 854.

Csilléry, G. and Ruskó, J. (1980): The control of a new tobamovirus strain by linked to anthocyanin deficiency in pepper (Capsicum annиum). Eucarpia Vth Meeting, 1983, Plovdiv, Bulgaria, 40-43.

Feldman, J. M. and Oremianer, S. (1972): An unusual strain of tobacco mosaic virus from pepper. Phytopath. Z., 75, 250-267.

Gáborjányi, R., Pogány, M. and Horváth J. (1997): A vírusok szerepe a paprikapusztulásban (Role of viruses in pepper decline). Növényvédelem, 33, 181-185.

Gáborjányi, R., Horváth J., Kovács J. and Kazinczi, G. (1998): Role of viruses in pepper decline in Hungary. Xth EUCARPIA Meeting on Genetics and Breeding of Capsicum and Eggplant. Avignon, France. Abstr., 129-132.

García-Luque, I., Serra, M. T., Alonso E., Wicke, B., Ferrero, M. L. and Díaz-Ruíz J. R. (1990): Characterization of a Spanish strain of pepper mild mottle virus (PMMV-S) and its relationship to other tobamoviruses. J. Phytopathology, 129, 1-8.

García-Luque, I., Ferrero, M. L., Rodríguez, J. M., Alonso, E., De La Cruz, A., Sanz, A. I., Vaquero, M. T., Serra, M. T. and Díaz-Ruíz, J. R. (1993): The nucleotide sequence of the coat protein genes and 3' noncoding regions of two resistance-breaking tobamoviruses in pepper shows that they are different viruses. Arch. Virol., 131, 75-88.

Green, S. K. and Kim, J. S. (1991): Characteristics and control of viruses infecting peppers: A literature review. Technical Bulletin No 18. Asian Vegetable Research and Development Center, Taipei, pp.60.

Horváth, J. (1969): Adatok a paprikafajták vírusokkal szembeni fogékonyságához és a paprikapatogén vírusok differenciálásához (Contributions to the susceptibility of paprika varieties to viruses and the differentiation of paprika pathogene viruses). Növénytermelés, 18, 79-88.

Horváth, J. (1993): A list of proposed letter codes for hosts and non-hosts of plant viruses. Acta Phytopathol. Acad. Sci. Hung., 28, 21-58.

Kiss, F. E. (1996): Virus diseases of greenhouse pepper in South Hungary. International Workshop on Biological and Integrated Pest Management in Greenhouse Pepper, Hódmezővásárhely, Hungary, Abstr. 119.

Linhart, Gy. and Mezey, Gy. (1890): A dohány mozaikbetegsége (The mosaic diseases of tobacco). Mezőgazdasági Szemle, 1-10.

Mayer, A. (1886): Über die Mosaikkrankheit des Tabaks. Landwirtsch. Vers. Sta., 32, 451-467.

McKinney, H. H. (1929): Mosaic diseases in Canary Islands, West Africa and Gibraltar. J. Agric. Res., 39, $557-558$.

McKinney, H. H. (1952): Two strains of tobacco mosaic virus, one of which is seed-borne in an etch-immune pungent pepper. Plant Dis. Rep., 36, 184-187.

Rast, A. Th. B. (1979): Pepper strains of TMV in the Netherlands. Med. Fac. Landb. Wet. Rijksuvin. Gent., 44, 617-622.

Rast, A. Th. B. (1988): Pepper tobamovirus and pathotypes used in resistance breeding. Capsicum Newsletter, $7,22$.

Sambrook, J., Fritsch, E. F. and Maniatis, T. (1989): Molecular Cloning: A Laboratory Manual, 2nd ed., Cold Spring Harbor Laboratory, Cold Spring Harbor, New York.

Salamon, P. (1993): Tobamovirus rezisztenciagének a Capsicum nemzetségben és a paprika rezisztencianemesítés hazai eredményei (Tobamovirus resistance genes in the genus Capsicum and Hungarian results of the breeding of paprika). In: Integrált termesztés a kertészetben (Integrated production in horticulture) 14, Budapest, 104-113. 
Salamon, P. and Beczner L. (1987a): Dulcamara yellow fleck virus (DYFV): a tobamovirus csoport új, Solanum dulcamara populációkban elterjedt, Magyarországon endemikus tagja (Dilcamara yellow fleck virus (DYFV): a new member of the tobamovirus group distributed in populations of Solanum dulcamara and endemic in Hungary). Növényvédelmi Tud. Napok 1987, Budapest, 83.

Salamon, P., Beczner L. and Hamilton R. I. (1987b): Dulcamara yellow fleck virus (DYFV): a new member of the tobamovirus group isolated in Hungary. VIIth International Congress of Virology. Edmonton, National Res. Council, Ottawa, Canada, pp. 329.

Selassie, K. G., Dumas De Vaulx R., Marchoux G. and Pochard E. (1981): Le virus de la mosaique du tabac chez le piment. I. Apparition en France du Pathotype P1,2. Agronomie, 1(10), 853-858.

Szirmai, J. (1950): Vírusok és vírusbetegségek (Viruses and virus diseases). In: Ubrizsy, G. (ed.): Növénykórtan (Plant Pathology). Akadémiai Kiadó, Budapest, 1952. pp. 193-232.

Tanzi, M., Betti, L. and Canova, A. (1989): PepMV infection in pepper seeds. Biological characterisation of some strains and their localisation in the seed. Phytopath. Medit., 28, 204-209.

Tenllado, F., García-Luque, I., Serra, M. T. and Díaz-Ruíz, J. R. (1994): Rapid detection and differentiation of tobamoviruses infecting L-resistant genotypes of pepper by RT-PCR and restriction analysis. Journal of Virol. Methods, 47, 165-174.

Tenllado, F., García-Luque, I., Serra M. T. and Díaz-Ruíz, J. R. (1997): Pepper resistance-breaking tobamoviruses: can they co-exist in single pepper plants? European Journal of Plant Pathology, 103, 235-243.

Tóbiás, I. and Csilléry, G. (1983): Virus diseases of pepper in greenhouse and plastic tunnel in Hungary. Eucarpia Vth Meeting, 1983, Plovdiv, Bulgaria.

Tóbiás, I., Rast, A. Th. B. and Maat, D. Z. (1982): Tobamoviruses of pepper, eggplant and tobacco: comparative host reactions and serological relationships. Neth. J. Pl. Path., 88, 257-268.

Tóbiás, I., Rast A. Th. B. and Maat, D. Z. (1983): Comparison of some tobamoviruses from pepper with U1 strain of TMV by test plants and serology. Proc. Int. Conf. Integr. Plant Prot., Budapest, 1983, 3, 46-52.

Tošić, M., Šutić, D. and Pešić, Z. (1980): Transmission of tobacco mosaic virus through pepper (Capsicum апnиит L.) seed. Phytopath. Z., 97, 10-13.

Wetter, C., Conti, M., Altschuh, D., Tabillion, R. and Van Regenmortel, M. H. V. (1984a): Pepper mild mottle virus, a tobamovirus infecting pepper cultivars in Sicily. Phytopathology, 74, 405-410.

Wetter, C. (1984b): Serological identification of four tobamoviruses infecting pepper. Plant Disease, 68 (7), 597-599.

Zatykó, L. (1982): Paprikatermesztés (Production of paprika). Mezőgazdasági Kiadó, Budapest, 388 pp. 